\title{
Komunikasi Politik di Era Media Sosial
}

\author{
Faridhian Anshari
}

Staff Pengajar STT PLN Jakarta

\begin{abstract}
The development of communication technology has penetrated the lives of human beings. One form of communication is the development of new media technologies who gave birth to social media. Political world is also not free from the influence of new media and social media. Social media are like two sides of a coin for political actors. On the one hand, the success by using social media is getting positive support. But on the other hand failure by using social media is the risk by damaging the image.

This paper discusses the challenges and opportunities of social media on political actors. Exposure to the use of social media in political communication becomes the first part of this paper. The second section discusses the challenges faced by political actors in the 2.o era. The third section gives an offer opportunities for political actors in the utilization of social media. There is also the fourth and final section is a conclusion that contains what should be done by political actors to minimize the risks and maximize the opportunities offered by social media.
\end{abstract}

Keywords: internet, new media, social media, political communication

\begin{abstract}
Abstrak
Perkembangan teknologi komunikasi telah merambah kehidupan umat manusia. Salah satu bentuk perkembangan teknologi komunikasi adalah media baru (new media) yang kemudian melahirkan media sosial. Dunia politik juga tak lepas dari pengaruh perkembangan media baru dan media sosial. Media sosial ibarat dua sisi mata uang bagi para aktor politik. Di satu sisi keberhasilan memanfaatkan media sosial dapat memungkinkan aktor politik mendapatkan dukungan positif. Tapi di sisi lain kegagalan memanfaatkan media sosial berisiko merusak citra yang dia miliki.

Tulisan ini membahas mengenai tantangan dan peluang dari media sosial terhadap para aktor politik. Pemaparan penggunaan media sosial dalam komunikasi politik menjadi bagian pertama dari tulisan ini. Bagian kedua membahas tentang tantangan yang dihadapi oleh para aktor politik di era 2.0 ini. Bagian ketiga memberikan tawaran peluang bagi aktor politik dalam pemanfaatan media sosial. Ada pun bagian keempat atau terakhir merupakan kesimpulan yang berisi apa yang sebaiknya dilakukan oleh para aktor politik untuk meminimalkan risiko dan memaksimalkan peluang yang ditawarkan oleh media sosial.
\end{abstract}

Kata kunci: internet, media baru, media sosial, komunikasi politik 


\section{Pendahuluan}

Perkembangan teknologi komunikasi telah merambah kehidupan umat manusia. Salah satu bentuk perkembangan teknologi komunikasi adalah media baru (new media) yang kemudian melahirkan media sosial (social media). Kehadiran media sosial juga mempengaruhi bidang politik. Studi di Amerika Serikat menunjukkan media sosial alat kampanye yang efektif. Sebelum era media sosial, politisi di Negeri Paman Sam sudah memanfaatkan internet untuk media berkampanye. (Chavez, 2012; Stietglitz \& Dang Xuan, 2012).

Di Ghana, dua kandidat presiden menggunakan SMS dan Twitter untuk mendulang suara. Ini merupakan kali pertama media sosial digunakan untuk berkampanye di negara tersebut. Di Zimbabwe, partai oposisi menggunakan website untuk menyebarkan pesan yang mengecam pemerintah berkuasa. Selain itu Lembaga Swadaya Masyarakat membentuk jaringan untuk memonitor pemungutan suara di 11 ribu bilik suara melalui SMS dan MMS. Hasilnya calon petahana (incumbent) Robert Mugabe kalah, tetapi intervensi Mugabe membuat Pemilu diulang dan dia menang (Riaz, 2010).

Menurut Silih Agung Wasesa, kehadiran media baru berbasis digital membuat informasi politik tidak hanya semakin masif,tetapi juga terdistribusi dengan cepat dan bersifat interaktif. Dengan karakteristiknya itu tidak sedikit aktor politik di sejumlah negara memanfaatkan media sosial proses kampanye politik. Selain itu media baru mampu untuk menjaring pemilih muda dan biayanya murah ("Aktor Politik Wajib Manfaatkan Media Sosial”, ugm.ac.id, 7 Juni 2013).

Partai politik di Indonesia sudah banyak yang memiliki akun Facebook, Twitter, dan YouTube, di samping website resmi parpol ("Parpol Serius Garap Media Sosial”, Kompas.com, 29 Mei 2013). Sementara politisi-politisi masing-masing memiliki akun pribadi seperti Menteri Komunikasi dan Informatika Tifatul Sembiring (twitter @tifsembiring), Menteri Pemuda dan Olahraga Roy Suryo (twitter@KRMTRoySuryo). Bahkan akun twitter presiden RI Susilo Bambang Yudhoyono (@sbyudhoyono) berstatus verified account, yang artinya sudah mendapatkan verifikasi dari pihak Twitter. Politisi lain yang memiliki akun twitter misal Prabowo (@Prabowoo8) dan Wiranto (@wiranto1947). Program kerja, pendapat mengenai isu terkini, atau pembicaraan-pembicaraan yang sifatnya ringan, menanggapi mention dari masyarakat, adalah hal-hal yang umumnya tercantum dalam linimasa Twitter para tokoh politik tersebut.

Media sosial memang menawarkan peluang bagi para aktor politik untuk bisa menjaring pemilih, berinteraksi secara langsung dengan publik sekaligus 
membentuk perbincangan yang "akrab" dengan publik. Tetapi di sisi lain, media sosial juga dapat membuat aktor politik menjadi bahan tertawaan atau bahkan caci maki dari publik. Sebuah pertanyaan kritis diajukan oleh Momoc (2011) terkait manfaat media sosial di ranah politik. Secara spesifik, Momoc membahas mengenai kampanye. Apakah dengan mengincar audiens online, apakah internet bisa membantu politisi untuk mendapatkan pemilih dalam jumlah besar? Apakah hal tersebut bisa berhasil jika politisi tersebut tidak memiliki kredibilitas di dunia riil?

\section{Pengaruh Media Sosial terhadap Komunikasi Politik}

Pengaruh media sosial dalam dunia politik khususnya dalam hal komunikasi politik, terutama dalam kampanye Pemilu (Chavez, 2012; Riaz, 2010; Stietglitz \& Dang-Xuan, 2012). Penting bagi institusi politik untuk berpartisipasi aktif dalam komunikasi politik yang berbasiskan media sosial, terutama dalam kampanye Pemilu. Media sosial selanjutnya menggambarkan sebagai sarana ideal dan basis informasi untuk mengetahui opini publik tentang kebijakan dan posisi politik, selain untuk membangun dukungan komunitas kepada politisi yang tengah berkampanye. Sejumlah penelitian menunjukkan politisi di seluruh dunia telah mengadopsi media sosial untuk menjalin hubungan dengan konstituen, berdialog langsung dengan masyarakat dan membentuk diskusi politik. Kemampuan menciptakan ruang dialog antara politisi dengan publik serta menarik minat pemilih pemula/pemilih muda membuat media sosial semakin penting bagi politisi (Stieglitz \& DangXuan, 2012)

Sebelum menggunakan media sosial para politisi sudah menggunakan internet untuk berkampanye. Internet bisa menjadi cara yang potensial dalam mendobrak politik demokrasi massa yang opresif yang menyuarakan suara dari bawah ke atas, yang kerap dengan power yang dimiliki, dimanfaatkan oleh penguasa untuk kepentingan golongannya. Internet diharapkan bisa menjadi media bagi mengalirnya informasi dua arah yang interaktif antara politisi dan pendukungnya. Internet menjanjikan memberikan forum yang seluas-luasnya bagi pengembangan kelompok kepentingan dan sebagai sarana penyaluran opini (Asih, 2011). Di Indonesia, penggunaan internet sebenarnya sudah dimulai sejak Pemilu 1997, di mana kontestan Pemilu saat itu: Golongan Karya, Partai Demokrasi Indonesia, dan Partai Persauan Pembangunan, masing-masing memiliki situs resmi. Informasi dalam situs tersebut meliputi program partai, pernyataan politik, susunan pengurus pusat/daerah, AD/ART, dan kesempatan dialog dengan pengurus. Pada Pemilu 2004 dan 2009 penggunaan internet 
semakin meningkat pada partai politik, individu calon legislator, calon presiden dan calon wakil presiden (Putra, 2011).

Keberhasilan menggunakan media sosial dipandang sebagai salah satu faktor kesuksesan Barack Obama memenangi pemilihan presiden Amerika Serikat. Sekitar 30 persen pesan-pesan kampanye Obama disampaikan melalui media baru (Riaz, 2010). Beberapa tahun sebelum Obama, terdapat nama Howard Dean yang mampu memanfaatkan internet untuk meraih atensi publik AS. Namun saat itu Dean kandas di konvensi nasional Partai Demokrat (Chavez, 2012). Di Inggris, makin banyak anggota parlemen menggunakan blog dan Yahoo Groups untuk mengkomunikasikan ide mereka dan mendengarkan ide orang lain (Gurevitch, et.al. 2009).

Bagaimana dengan di Indonesia? Media sosial memang mulai dilirik dalam kurun waktu sekitar dua tahun terakhir. Para pendukung Joko Widodo dan Basuki Tjahja Purnama dalam kampanye pemilihan gubernur DKI Jakarta memanfaatkan YouTube untuk memposting video kampanye kreatif mereka. Bahkan sempat ada game online yang memiliki alur cerita seperti game Angry Birds, dengan tokoh utama Jokowi.

\section{Tantangan Media Sosial bagi Aktor Politik}

Di bagian sebelumnya sudah dipaparkan bahwa media sosial masih belum dimanfaatkan dengan baik oleh para aktor politik di Indonesia. Tantangan pertama adalah hilangnya batas-batas status sosial di dunia media sosial. Menurut Coutts \& Gruman (2005: 254) dalam komunikasi yang termediasi dengan komputer, maka para peserta komunikasi akan mendapatkan kesetaraan partisipasi yang lebih luas daripada tatap muka. Pendapat tersebut memang mengacu pada aktivitas komunikasi dalam organisasi. Namun relevan apabila dibawa ke dalam konteks komunikasi politik di era media sosial. Dengan adanya media sosial, maka para aktor politik pun harus menyadari meskipun dia secara riil adalah pejabat tinggi atau partai politik yang berkuasa, tetapi posisinya di media sosial akan setara dengan user lain. Maka dari itu para aktor politik harus siap-siap saja menghadapi kritik (bahkan beberapa di antaranya cenderung pedas) user lain.

Media sosial merupakan rimba raya, dan praktis tidak ada peraturan di dalamnya (Fitch, 2009). Apabila tantangan itu tidak dihadapi dengan bijak, maka hasilnya aktor politik tersebut justru malah menjadi bahan cibiran di dunia maya. Cukup marak diberitakan bagaimana Ibu Negara, Ibu Ani Yudhoyono, beberapa kali terlibat perdebatan -dan itu mengenai hal-hal yang tidak substantif-dengan user lain di Instagram. Selain itu para aktor politik tidak bisa lagi menggunakan media sosial sebagai sarana untuk "curhat”. 
Media sosial telah mengaburkan pemahaman orang, apakah yang dikatakan tersebut merupakan sikap resmi atau hanya ungkapan pemikiran atau perasaan dia sebagai pribadi. Sikap resmi atau institutional rhetoric dan ungkapan pribadi atau everyday talk sering tumpang tindih (Finet, 2001: 274-276). Seseorang akan salah persepsi apakah curhat yang dilakukan oleh aktor politik di media sosial merupakan ungkapan dirinya sebagai pribadi atau mewakili institusinya.

Persoalannya aktor politik di Indonesia masih belum menyadari bahwa dalam berkomunikasi di media sosial memerlukan kemampuan tersendiri. Kemampuan di sini tentu tidak hanya kemampuan teknis, tetapi mentalitas. Kehadiran media sosial menuntut para pelaku politik untuk beradaptasi. Namun para pelaku politik tersebut sering kesulitan dalam fase adaptasi ini (Chavez, 2012). Ada beberapa hal yang berkaitan dengan "mentalitas lama" (old mentalities) seperti yang disebutkan di atas - dan hal ini umumnya dialami oleh organisasi yang menggunakan media sosial.

Salah satunya adalah mengabaikan sifat interaktif yang ada di media sosial. Dalam era politik kontemporer, politisi harus memikirkan audiens interaktif dan kapasitas mereka untuk menjawab, menanggapi, mendistribusikan dan memodifikasi pesan yang mereka terima. Penelitian Asih (2011) mengungkapkan bahwa partai politik di Indonesia mayoritas belum memaksimalkan media sosial dan media baru. Faktor interaktifitas diabaikan. Dari 34 parpol peserta Pemilu 2009, seluruhnya memiliki website. Sayangnya situs web tersebut belum dimanfaatkan secara maksimal sebagai media komunikasi dua arah. Hampir di semua website parpol tidak tersedia forum yang memungkinkan komunikasi dua arah. Kalau pun tersedia, forum ini tidak dapat diakses. Facebook dan Twitter yang digunakan oleh politisi dan partai politik ternyata isinya hanya untuk menginformasikan hal-hal yang baik-baik saja. Transaksi informasi yang terjadi didominasi oleh posting-posting yang disampaikan oleh simpatisan parpol atau politisi. Politisi dan partai politik sekadar latah menggunakan jejaring sosial untuk berinteraksi. Media sosial masih dimanfaatkan sebagai media kampanye, belum interaktif, belum aspiratif. Padahal media sosial memiliki potensi sebagai sarana untuk mendengarkan suara masyarakat.

Di era interaktif digital, produksi pesan dan citra politik malah justru menjadi hal yang rawan untuk "diganggu". Pelaku politik harus mempertimbangkan kemungkinan bahwa pesan-pesan mereka akan dimodifikasi oleh pihak lain ketika pesan tersebut disampaikan melalui media sosial. Lingkungan media digital tidak menghargai integritas informasi: ketika informasi itu sudah dipublikasikan secara online, maka siapa pun bebas untuk memodifikasinya (Gurevitch, et.al, 
2009). Para pengguna internet tak tertarik untuk mencari rekam jejak atau program yang ditawarkan oleh politisi. Sebaliknya, ada kecenderungan di masa kampanye Pemilu, internet justru digunakan untuk mengolok-olok politisi dan menyerang politisi yang tidak disukai (Momoc, 2011).

\section{Media Sosial Sebagai Sarana Branding: Sebuah Tawaran}

Kelemahan partai politik dan politisi di Indonesia adalah hanya "menyapa" konstituen biasa/pendukung biasa setiap lima tahun saja, yakni menjelang pemilihan umum. Jika tidak mendekati pemilihan umum, partai atau politisi hanya menyapa pendukung-pendukung yang kaya (Wasesa, 2011). Padahal masyarakat biasa pun perlu disapa. Dalam proses branding kepada masyarakat, dibutuhkan berbagai cara agar penyampaian pesan dapat efektif tertanam ke benak publik. Salah satu cara yang dianggap efektif dan efisien saat ini adalah melalui penggunan new media. Dengan mengandalkan kemampuan internet dalam menyebarkan pesan secara many to many, tokoh personal tersebut secara cepat dapat merasakan efek positif yang diberikan oleh new media. Branding menggunakan new media yang diwakili oleh media sosial dapat berefek positif untuk perusahaan maupun dalam kasus ini adalah personal. Hal ini didukung oleh kemampuan internet dalam menjangkau masyarakat yang sebelumnya terabaikan lewat branding dengan cara lama. Penelitian ini juga dilengkapi oleh kemampuan media sosial yang dalam kesehariannya dapat menggunakan bahasa masyarakat sehingga kualitas pesan dapat menyebar luas kepada publik (Aino Majja Toppi, 2012)

Kesuksesan branding melalui media sosial ditentukan oleh pengelolaan media sosial secara up to date dan senantiasa menjaga komunikasi secara konsisten dengan menggunakan struktur percakapan yang sedang berkembang dalam lingkungan masyarakat (Lipiainen \& Karjaluoto, 2012). Menjaga pengelolaan media sosial yang selalu up to date serta melayani publik dalam memberikan informasi tidaklah mudah. Konsistensi menjadi kata kunci yang perlu dipahami seluruh pihak. Selain itu politisi juga menghadapi tantangan lain terkait penggunaan media sosial sebagai upaya pembentukan branding yakni menampilkan pribadi sesuai dengan harapan masyarakat (Guervitch, et.al., 2009).

Berdasarkan penelitian yang berkembang, penggunaan media sosial mempunyai beberapa keuntungan strategis. Secara garis besar keuntungan yang dihasilkan dari branding menggunakan media berbasis internet adalah mudah, murah, praktis, dan efektif (Anshari, 2013).

Konsep mudah yang diusung dari penggunaan media sosial adalah kemudahan yang ditonjolkan dari sistem 
internet dan penggunaan media sosial. Dengan sekali tekan "push" dari satu tempat, sebuah pesan dapat cepat menyebar dan dibaca serta diketahui oleh seribu bahkan seluruh orang. Bayangkan dengan pengunaan branding model lama yang memakan space di beberapa titik pentig. Belum lagi harus menyebarknnya ke seluruh kota di Indonesia. Lewat media sosial, penyebaran cukup dari satu titik namun jangkauan langsung menyebar ke seluruh pelosok yang masih terjangkau daya internet.

Harga yang harus dikeluarkan juga menjadi pertimbangan utama dari penggunaan media sosial sebagai alat branding. Cukup dengan mengoptimalkan peran fitur di media sosial, maka pesan akan sampai dengan sendirinya kedalam benak masyarakat. Hanya dengan kekuatan internet satu pesan dapat tersebar ke banyak pihak, sesuai dengan sifat internet, yakni many to many. Namun masih banyak juga tokoh politik yang mengedepankan old fashion branding dengan pemasangan baleho, spanduk, hingga poster yang menonjolkan kemampuan serta kelebihan yang ditawarkan oleh dirinya jika terpilih. Hal ini dikarenakan banyak tokoh politik yang masih percaya bahwa pemilih yang tinggal di pelosok tidak mahir dan belum paham akan penggunaan internet. Bayangkan dengan penggunaan media sosial, berapa harga yang bisa di hemat. Biaya pemasangan spanduk dan sejenisnya dapat diminimalisir dengan ketetpatan dan ketelatenan dalam memberikan informasi di media sosial.

Praktis juga menjadi keuntungan tersendiri, sifat branding yang cukup praktis karena dapat menjangkau seluruh kalangan, tanpa perlu mengkotak-kotak an warga. Cukup praktis jika dibandingkan dengan old fashion branding yang harus memecah konsentrasi serta jenis pesan yang akan disampaikan untuk golongan warga kelas atas, kelas menegah, dan kelas bawah yang belum mampu. Namun dengan jumlah pengguna media sosial di Indonesia yang mencapai angka 75 Juta pengguna, jelas merupakan cara yang lebih praktis jika branding dipusatkan kepada penggunaan media sosial.

Namun begitu dari sisi efektifitas belum dapat dilihat dengan tepat, dikarenakan fokus dari penelitian ini bukanlah efektifitas dari branding menggunakan media sosial. Efektifitas baru dapat diukur setelah usainya pemilihan tokoh politik tersebut. Namun dari banyaknya penelitian serta contoh studi kasus yang terjadi di lapangan, dapat dilihat bahwa penggunaan media sosial sebagai sarana branding dapat berjalan mulus. Dengan mengambil contoh studi kasus pemilihan gubernur DKI Jakarta pada tahun 2012, yang meloloskan Jokowi - Ahok sebagai pemenenang. Proses kampanye hingga branidng yang mereka jalankan banyak menggunakan bantuan media sosial seperti facebook, twitter, hingga youtube. Sehingga tidk salah jika 
ada kemungkinan branding yang dijalankan dengan media sosial dapat menuai hasil yang positif.

\section{Penutup}

Banyaknya keuntungan yang ditawarkan dalam pengunaan media sosial sebagai ajang branding tokoh politik, juga tidak boleh lepas dari beberapa kunci penting yang harus tetap diperhatikan. Dikarenakan media sosial termasuk sebagai salah satu alat untuk berkomunikasi dengan audience serta calon pemilihnya, maka sisi komunikasi harus selalu terkanding didalamnya. Dalam hal ini, variabel yang dibutuhkan adalah kandungan message atau pesan yang ingin di sampaikan kepada khalayak harus sesuai dengan target yang ingin dicapai. Hal lain yang juga menjadi variabel adalah sisi komunikatif atau terciptanya komunikasi dua arah dengan audience sebagai calon pemilih.

Ada kalanya sebuah tim sukses tokoh politik tertentu terlalu terburu-buru dan cepat dalam menyampaikan pesan lewat media sosial tanpa memperhatikan beberapa kaedah tertentu. Terkadang hanya masalah kuantitas pesan yang diperhatikan tanpa melihat sisi kualitas atau kandungan pesan. Kampanye diri atau branding yang disampaikan lewat pesan di media sosial harus sesuai dengan keinginan serta target audience. Seperti twitter, path, dan facebook pesan yang disampaiakan harus mempunyai bahasa yang selaras dengan masing-masing targe audience. Dikarenakan pengguna media sosial masih besar diangka pengguna remaja yang kelak menjadi pemilih pemula, maka bahasa yang digunakan adalah bahasa keseharian anak muda, atau dapat dikatakan sebagai bahasa gaul.

Bahasa yang diguakan dalam penyampaian pesan sebaiknya adalah bahasa yang digunakan juga oleh audience sehari-hari. Penggunaan kata serta kalimat baku dapat dilebur menajdi lebih lentur. Seperti salah satunya contoh penggunaan kata "tidak" dapat diganti dengan kata "ngga". Bahasa yang tidak baku akan cepat melebur dan beradaptasi dengan masyarakat, sehingga isi pesan dapat lebih tercapai.

Selain penggunaan bahasa yang sesuai dengan situasi lingkungan sekitar, gambar yang berbau motivasi serta unik juga sebaiknya ikut disertakan dalam pesan tersebut. Ada baiknya jangan hanya menyampaikan kelebihan seorang tokoh secara terang-terangan, namun disampaiakn lewat kandungan tulisan pesan. Seperti kata-kata motivasi, yang secara tersirat menggambarkan bahwa tokoh tersebut mempunyai jiwa yang bijak. Penyampaian pesan, seharusnya tersirt untuk menggambarkan kandungan pesan itu sendiri.

Lifestyle atau gaya hidup juga menjadi salah satu jalan untuk masuk dan cepat beradaptasi dengan audience. Lewat tampilan pesan yang sedang trend dijamannya, sebuah pesan akan cepat masuk ke benak audience. Kita ambil 
contoj penggunaan video You Tube "Parodi One Direction" yang ditujukan untuk memilih Jokowi dn Ahok untuk Jakarta baru. Video yang sudah di tonton orang hingga 10 juta kali ini, jelas mewakili lifestyle generasi muda sebagai pemilih baru. Tiga kunci utamanya yakni: Video unik (parodi), lagu milik boyband yang tengah naik daun One Direction, dan You Tube.

You tube jelas menjadi wakil media sosial dalam menyampaiakn pesan lewat cara lain bukan hanya dalam bentuk tulisan kepada audience. Sedangkan pesn berbed yang ditawarkan adalah lewat video unik, dimana rata-rata pengguna you tube lebih tertarik membuka youtube untuk browsing video unik serta lucu. Parodi yang menjadi ciri khas lawakan Indonesia tahun 9oan awal ditonjolkan dlam bentuk lagu dan musik terpopuler pada saat itu. Sedangkan One Direction dengan lagunya yang berjudul What Makes You Beautiful menjadi lagu paling populer dan di cari sepanjang tahun 2011. Sehingga langkah yang diambil oleh tim sukses Jokowi dengan membrandingkan lewat parodi lagu di Youtube menjadi salah satu titik balik penting dalam kemenangan Jokowi Ahok menjadi gubernur DKI.

Selain penggunaan bahasa, sisi komunikatif juga perlu dijangkau oleh para tokoh politik yang membrandingkan dirinya lewat media sosial. Terkadang pesan yang disampaikan hanya berbentuk komunikasi satu arah tanpa memperdulikan masukan maupun kritik dari audience sebagai si penerima pesan. Hal ini dapat dilihat dari banyaknya status atau tweet di media sosial twitter beberapa tokoh politik yang lebih mengedepankan tulisan terkait dirinya, dan terlihat jarang menulis status yang menyertakan balasn mention untuk audience mupun followers yang sudah bertanya atau memberi masukan. Komunikasi yang baik dalam media sosial memang harus selalu berbentuk dua arah. Namun yang terkadang menjadi kendala adalah, betuk balasan yang harus diberikan untuk kritikan yang diajukan oleh para audience. Sehingga terkadang terkesan, menghiraukan masukan dan kritik yang diajukan oleh audience.

Didalam penyampaian komunikasi dua arah yang menggunakan balasa pesan dari audience, juga tetap diperhatikan bahasa serta rangkaian kata yang digunakan. Karena lewat beberapa susunan kalimat, akan menggambarkan karakter sang tokoh politik. Serta kedepannya, rangkaian kalimat tersebut dapat membawa pandangan atau citra yang positif atau bahkan dapat disalahartikan oleh audience sehingga mengakibatkan cercaan serta hujatan yang terus menerus oleh audiene, yang lebih dikenal dengan nama media sosial bullying.

Sedangkan peluang lain yang dapat dijadikan penelitian lanjutan melalui branding lewat media sosial adalah pengukuran kecepatan 
penyampaian pesan, sehingga dapat dihitung dari penelitian secara kuantitatif dan kualitatif. Hal lain yang belum diteliti lanjut adalah pengukran jumlah pesan yang harus disampaiakan setiap harinya, agar dapat dilihat sisi efektifnya.

\section{DAFTAR PUSTAKA}

Anshari, Faridhian. 2013. "Radio Streaming Sebagai Alternatif Corporate Branding. Studi Kasus Radio Streaming Elti Channel Sebagai Corporate Branding ELTI Yogyakarta Tahun 2012. Tesis Fakultas Ilmu Sosial dan Ilmu Politik, Jurusan Komunikasi. Program Pascasarjana Universitas Gadjah Mada, Yogyakarta

Asih, Irsanti Widuri. 2011. "Media Sosial dan Politik: Sarana E-Democracy atau Sekadar Pepesan Kosong?” dalam Proceeding Semnas FISIPUT, hal.452-465. http://www.pustaka.ut.ac.id/dev25/ pdfprosiding2/fisip201131.pdf, diakses 21 Juli 2013

Chavez, Jonathan. 2012. \#Fail: The Misuse of Social Media Campaign in the 2012 US Presidential Campaign.

http://www.tcd.ie/policyinstitute/assets/pdf/PL Chavez Ma rch12.pdf, diakses 22 Juli 2013

Coutts, Larry M., \& Gruman, Jamie A. 2005. "Applying Social Psychology to Organizations" dalam Applied Social Psychology: Understanding and Addressing Scial and Practical Problems. Frank W. Schneider, et.al (Eds). Thousand Oaks: SAGE.

Fitch, Kate. 2009. "Making friends in the Wild West: Singaporean public relations practitioners' perceptions of working in social media” dalam PRism 6(2), hal 1-14 http://www.prismjournal.org/filead min/Praxis/Files/globalPR/FITCH. pdf , diakses 3 Februari 2013

Finet, Dayna. 2001. "Sociopolitical Environments and Issues" dalam The New Handbook of Organizational Communication: Advances in Theory, Research, and Methods. Fredric M. Jablin \& Linda L. Putnam (Eds). Thousand Oaks: SAGE

Guervitch, Michael. , Coleman, Stephen., Blumler, Jay G. 2009. "Political Communication -- Old and New Media Relationships" dalam The ANNALS of the Amreican Academy of Political and Social Science 625, hal.164-182. http://www.ensani.ir/, diakses 21 Juli 2013

Lipiainen, Heini dan Karjaluotto, Heikki. 2012. "Suggestions For B2B Brand On Surviving In The Digital Age." Journal University of Helsinki. Vol 3, hal. 1-6.

Momoc, Antonio. 2011. "New Media and Social Media in the Political 
Communication" dalam The 6th Edition of The International Conference European IntegrationRealities and Perspectives, hal.556562. http://www.proceedings.univdanubius.ro/index.php/eirp/article/ view/797/725, diakses 21 Juli 2013

Putra, Afdal Makkuraga. 2011. "Media Baru dan Fenomena Komunikasi Politik pada Pemilukada di Propinsi Banten 2011" dalam Jurnal UMN Volume III Nomor 2 Desember, hal.23-34.

http://library.umn.ac.id/jurnal/pub lic/uploads/papers/pdf/b7eba2cge4 4a4aa1e8ce3b833fefde3b.pdf, diakses 22 Juli 2013

Riaz, Saqib. 2010. "Effects on New Media

Technologies on Political

Communication" dalam Journal of

Political Studies, Vol. 1, Issue 2

University of the Punjab Lahore, hal. 161-173.

http://pu.edu.pk/images/journal/p ols/Currentissue-pdf/saqib10.pdf, diakses 21 Juli 2013

Stieglitz, Stefan \& Dang-Xuan, Linh. 2012. Social media and political communication: a social media analytics framework. http://www.researchgate.net/public ation/235632721 Social Media an d Political Communication A Social Media Analytics Frame work/file/79e41512111a26d3f3.pdf , diakses 21 Juli 2013
Toppi, Aino Maijja. 2012. "Corporate Brand Communication Through Social Media In industrial Setting." Journal University of Honolulu. Vol 2. Hal 36-45.

Wasesa, Silih Agung. 2011. Political Branding \& Public Relations. Jakarta: Gramedia Pustaka Utama

\section{Berita}

"Media Sosial Strategis Jaring Pemilih Pemula”. Antara, Senin 3 Juni 2013, 14:43 WIB http://www.antaranews.com/berita L378094/media-sosial-strategisjaring-pemilih-pemula, diakses 21 Juli 2013

"Parpol Serius Garap Media Sosial”. Kompas.com, 29 Mei 2013, 09:07 WIB http://nasional.kompas.com/read/2 013/05/29/09070488/Parpol.Seriu s.Garap.Media.Sosial, diakses 21 Juli 2013

"Aktor Politik Wajib Manfaatkan Media Sosial”. www.ugm.ac.id, 7 Juni 2013. http://ugm.ac.id/id/berita/7884aktor.politik.wajib.manfaatkan.medi a.sosial, diakses 21 Juli 2013 
Jurnal komunikasi, Volume 8, Nomor 1, Oktober 2013 